USGS-CIRC--903

TI85 900597

\title{
Disposal of High-Level. Nuclear Waste Above the Water Table in Arid Regions
}

By Eugene H. Roseboom, Jr.
GEOLOGICA
S UR VEY
CIRCULAR
903 
United States Department of the Interior JAMES G. WATT, Secretary

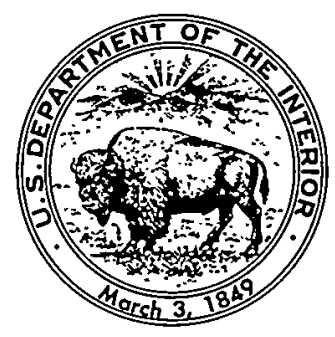

\section{Geological Survey}

Dallas L. Peck, Director 


\section{CONTENTS}

Abstract

Introduction

Ground water and heat-The primary concerns in any repository

Benefits of interim storage

Fully retrievable disposal

The unsaturated zone

Strategies for disposal in the unsaturated zone --_-----

Purpose

Principal differences associated with repository location

in the unsaturated zone

Site exploration and characterization

Predictability of performance
Waste package design

Repository design and sealing

Monitoring, retrieval, and decommissioning -_-_-_-_-

Principal concerns associated with repository location in the unsaturated zone

Exhumation by natural processes

Future change to wetter climate

Exhumation by our uninformed descendants --.---_-

Possible future release of gaseous fission products if spent fuel is a waste form

Conclusions

References
Page

8

11

15

16

16

17

17

17

19

20

\section{ILLUSTRATIONS}

FIGURE 1. Diagrammatric representation of a repository in the saturated zone and in the unsaturated zone

2. Diagram illustrating ways of emplacing canisters in tunnels in the unsaturated zone to allow both heat removal by circulation of air and drainage of water

TABLE

TABLE 1. Hypothetical concentrations of "permissible" releases of radionuclides and their solubilities 


\section{DISCLAIMER}

This report was prepared as an account of work sponsored by an agency of the United States Government. Neither the United States Government nor any agency thereof, nor any of their employees, make any warranty, express or implied, or assumes any legal liability or responsibility for the accuracy, completeness, or usefulness of any information, apparatus, product, or process disclosed, or represents that its use would not infringe privately owned rights. Reference herein to any specific commercial product, process, or service by trade name, trademark, manufacturer, or otherwise does not necessarily constitute or imply its endorsement, recommendation, or favoring by the United States Government or any agency thereof. The views and opinions of authors expressed herein do not necessarily state or reflect those of the United States Government or any agency thereof. 


\section{DISCLAIMER}

Portions of this document may be illegible in electronic image products. Images are produced from the best available original document. 


\title{
Disposal of High-Level Nuclear Waste Above the Water Table in Arid Regions
}

\author{
By Eugene H. Roseboom, Jr.
}

\begin{abstract}
Locating a repository in the unsaturated zone of arid regions eliminates or simplifies many of the technological problems involved in designing a repository for operation below the water table and predicting its performance. It also offers possible accessibility and ease of monitoring throughout the operational period and possible retrieval of waste long after. The risks inherent in such a repository appear to be no greater than in one located in the saturated zone; in fact, many aspects of such a repository's performance will be much easier to predict and the uncertainties will be reduced correspondingly. A major new concern would be whether future climatic changes could produce significant consequences due to possible rise of the water table or increased flux of water through the repository. If spent fuel were used as a waste form, a second new concern would be the rates of escape of gaseous iodine-129 and carbon-14 to the atmosphere.
\end{abstract}

\section{INTRODUCTION}

Hydrologists divide the subsurface into two distinct environments, a zone of ground-water saturation whose upper surface is the water table and an unsaturated zone that extends from the water table to the land surface. The United States Government's program and all foreign programs for developing permanent disposal facilities for high-level nuclear wastes have been aimed at placing such facilities in the saturated zone. However, the concept of a repository in the unsaturated zone above the water table now has begun to receive serious attention. The site being considered for the first such repository, Yucca Mountain at the Nevada Test Site, was originally chosen for study because of potentially favorable host rocks below the water table (Dixon and Glanzman, 1982; Dixon and Hoover, 1982; Scott, 1983). ${ }^{1}$
Winograd $(1972,1974)$ proposed placing nuclear waste in the unsaturated zone and recently summarized the advantages associated with using the thick unsaturated zones of the southwestern United States as potential environments for the disposal of solidified radioactive wastes, with particular emphasis on shallow burial (50-300 feet) of transuranic (TRU) wastes (Winograd, 1981).

A report of the Panel on Hanford Wastes, Committee on Radioactive Waste Management, National Academy of Sciences $(1978$, p. 3) suggested that a repository for the high-level defense wastes at Hanford, Wash., could be located in the unsaturated zone in a "tunnel or adit driven into the Rattlesnake Hills. Technical appraisal of both alternatives (that is, saturated and unsaturated zone repositories) is urgent but immediate emphasis should be on the tunnel into the hills [italics added]. A repository in the hills has the potential advantages of lesser cost, a drier environment and a longer path of travel for ground water to reach the biosphere." The panel also noted that:

* * * Such a system would be above, rather than below, the regional water table, and if properly engineered, should remain dry at least much of the time. It would have the advantages of greater ease of construction, greater distance from the [Columbia] river, easier retrieval of waste canisters if this should prove

\footnotetext{
${ }^{1}$ As knowledge of the Yucca Mountain site grew, some members of a Peer Review Committee, made up of representatives from universities and industry, raised ques tions as to the possible utilization of potential host rocks in the unsaturated zone. In February 1982, several scientists of the US. Geological Survey (USGS), in a letter to the Department of Energy Program Manager for the Nevada Nuclear Waste Storage Investigations Program, summarized the hydrogeologic conditions that should be present in the unsaturated zone beneath Yucca Mountain and concluded that they should provide a very favorable environment for waste disposal. At about the same time. the USGS sent a letter to the Nuclear Regulatory Commission (NRC) suggesting how NRCproposed rule 10 CFR Part 60, which was specifically limited to repositories in the saturated zone, might be modified to include those in the unsaturated zone. A subsequent draft of 10 CFR Part 60 covers both zones.
} 
necessary, and less difficulty in sealing when the repository has been filled ****. The repository could be maintained at atmospheric pressure, and ventilation by passive circulation of air would be easy. The quantity of ground water that might percolate through the inferred perching bed presumably would be so small that it would drain downward through the floor of the repository; or, if not, it could be readily diverted around the repository.

Wollenburg and Korbin $(1982,1983)$, in a study prepared for the Nuclear Regulatory Commission (NRC), reviewed the literature to assess the advantages and disadvantages of nuclear waste disposal above the water table in alluvium-filled valleys and in tuffaceous rocks in topographic highs. They concluded that the unsaturated zone in alluvium or tuffaceous rocks of the Basin and Range province are strong candidate environments for nuclear waste disposal and should be investigated as comprehensively as other geologic settings under consideration.

Because the unsaturated zone provides a relatively dry environment and because the behavior of whatever water may be present is generally predictable, the unsaturated zone appears to simplify a number of problems that have arisen with regard to disposal of high-level waste in the saturated zone. At the same time, a few new problems appear, which need to be addressed. The intent of this paper is to point out some of the differences between the saturated and unsaturated zones that should be considered in locating and designing a system of waste disposal that could take advantage of the unsaturated environment.

I have drawn heavily upon the ideas of Isaac J. Winograd as expressed in his papers and in numerous discussions; without his help, this paper would not have been written.

\section{GROUND WATER AND HEAT-THE PRIMARY CONCERNS IN ANY REPOSITORY}

The main technical problems of developing a mined geologic repository stem from a single prime concern, ground water as a possible radionuclide transporting agent. Water is the only effective transporting agent that could return the waste to the biosphere, short of physical exhumation due to erosion, meteorite .impact, volcanic eruptions, and similar processes that are relatively unlikely to disrupt a repository. Consequently, most technical efforts are aimed at minimizing the contact of water with waste or at making certain that the consequences of such contact will be environmentally acceptable over thousands of years.

Ground water, however, is a very complex transporting agent with regard to predicting in detail both its physical movements and its chemical interactions with the many elements comprising the rocks and waste. Thus much work is being devoted to developing leach-resistant waste forms and corrosion-resistant containers, predicting groundwater paths and rates of flow at potential sites, determining the traveltimes of radionuclides and their sorption by natural materials, developing methods of sealing boreholes and shafts, and predicting or evaluating the consequences of possible future natural events and processes that could affect the hydrology. (For summaries, see U.S. Department of Energy (1980) and Klingsberg and Duguid (1980).)

The thermal load placed on the environment during the first few hundred years by buried highlevel waste adds a major complication (Lawrence Berkeley Laboratory, 1980). Thermal energy's potential for fracturing the surrounding rocks, changing their strength, and allowing greater amounts of water to contact the waste package must be carefully evaluated. Heat can break down sorptive minerals such as clays or zeolites and release bound water. Heat increases chemical reaction rates and makes new reactions possible, greatly increasing the difficulty of predicting the consequences of chemical interactions of water, waste, and rock. Thermal convection could increase the movement of water through a repository, as it does in natural geothermal areas. The warmed waters also transport the heat, making modeling of both the local thermal-mechanical and hydrologic regimes more complex and less predictable. Solution of minerals in the warmer rocks and their deposition in the cooler rocks further complicate the process.

In appropriately designed repositories above the water table in arid regions, the waste could be expected to remain nearly dry indefinitely (Winograd, 1981). In addition, there is the possibility of removing most of the heat by ventilation during the operational phase of the repository. Thus many of the foregoing technical problems could be significantly diminished; some may require more modest measures for their solution, and others simply may be eliminated. 


\section{BENEFITS OF INTERIM STORAGE}

Storage away from reactors has been proposed as a temporary measure when the onsite storage pools of electric utilities fill up with spent fuel and when repositories are not yet available. Zen (1980) recently has summarized other reasons for considering interim storage. At the present time, repositories in the United States are being designed to accept either spent fuel or reprocessed waste. Spent fuel contains both plutonium and uranium that could be extracted and further used as reactor fuel. There are other elements and isotopes present that could be useful if their extraction became economical. If we bury spent fuel, we may be burying resources that an energy-hungry and more technologically advanced world may desire to retrieve in the future. Will we have placed these where they can be exhumed only at a high cost and at risk to human life? Other benefits of interim storage are reducing the thermal output of the waste prior to disposal, reducing the radiation hazards of reprocessing, and keeping options open for future methods of disposal such as transmutation or disposal in space.

\section{FULLY RETRIEVABLE DISPOSAL}

The unsaturated zone offers the possibility of fully retrievable disposal. Fully retrievable disposal, as proposed here, combines both retrievable storage and permanent disposal; the waste is at its final resting place, and removing the waste is a planned option.

A certain degree of retrievability is already required in the design of a repository. NRC-proposed rule 10 CFR Part 60 (NRC, 1981) requires that the system be designed with the option to retrieve the waste for up to 50 years, should the repository turn out to be unacceptable in its performance. Evaluations of how one might retrieve waste from typical repositories in the saturated zone (Wilems and others, 1980; Kaiser Engineers, Inc., 1980) indicate that problems could be formidable and the costs high. Thus it appears likely that, in the saturated zone, retrieval would be attempted only under very dire circumstances, once a section of the repository had been filled with waste and backfilled. Even though retrieval is very unlikely to be needed, designing to allow for it increases the cost of the repository; the increase in cost rises with the duration of the desired period of retrievability (Wilems and others, 1980, p. 75).

As I shall show subsequently, the unsaturated zone probably could provide both permanent safe disposal and the option to retrieve the waste without great difficulty or danger, should reprocessing become a viable option at some time in the future or should the proposed repository prove unsound for some unforeseen reason.

\section{THE UNSATURATED ZONE}

In areas of moderate rain fall, the unsaturated zone can range from zero to several hundred feet in thickness. Water soaking into the land surface moves downward through the unsaturated zone to the water table. In desert areas, the unsaturated zone can extend to depths of 2,000 feet or more. In a typical desert environment, the few inches of annual precipitation is dissipated mostly as surface runoff, turning the dry gulches and washes into torrent-filled flumes for brief periods. The small amount of the precipitation that does soak into the soil is largely (and in warm or dry years, entirely) returned to the air by evapotranspiration (see, for example, National Academy of Sciences, 1978, p. 147-150).

The behavior of the water that does enter the subsurface is determined by the properties of the underlying rocks. If the underlying rocks are highly fractured, the movement of water downward through the unsaturated zone can be quite rapid. For example, Clebsch (1961, p. C124) estimated, by the tritium concentration method, that the age of ground-water samples from the U12e tunnel located 500 feet vertically below the east slope of Rainer Mesa and about 1,200 feet diagonally below the caprock (Thordarson, 1965, p. 74) was in the range of greater than 0.8 year but less than 6 years. On the other hand, in highly porous media with high bulk capillarity, the vertical movement of water becomes so slow that it is questionable whether movement occurs at all. Much of the water within the pore spaces of the rocks is simply held by capillary forces, moving neither up nor down, even though the rock may be nearly saturated; that is, the rock cannot accommodate additional water in its interstices (Thordarson, 1965, p. 26). Tunnels through such 
rocks at the Nevada Test Site were dry except for flow through fractures. Such fractures usually drained completely within a few weeks or months, but water dripped from some fractures for 2 years or more (Thordarson, 1965, p. 39). Fracture water also was closely associated with faults.

\section{STRATEGIES FOR DISPOSAL IN THE UNSATURATED ZONE}

There are at least two basic strategies for disposal of wastes in the unsaturated zone: (1) placing the waste in rocks of high fracture permeability to assure good drainage of the repository and (2) placing the waste in unsaturated rocks of high bulk capillarity that prevents water from entering the repository and draws up any that might enter.

The first strategy is most effective if the highly fractured host rock is capped by a layer of porous, but unsaturated, rocks with few open fractures (Winograd, written commun., May 11, 1982). Geotechnical Engineers, Inc. (1979, p. 68), notes that rock that is overlain by about 30 to 60 feet of soil would have the same lack of infiltration that is believed to exist in thick soil layers in arid climates. A layer of unwelded tuff or shale could provide a similar situation. Such highly porous rocks would be natural capillary barriers to recharge. Because of their low permeability, if these porous rocks should become nearly saturated, they still will dampen any surges of recharge from rare extreme precipitation events. At Yucca Mountain, a vitric bedded tuff sequence separating the $\mathrm{Pah}$ Canyon and Yucca Mountain members of the Paint Brush Tuff could provide this feature. A second desirable feature is for the host rock to be underlain by a barrier to radionuclide migration. This should be a relatively porous rock with few vertical fractures and a high content of clay or zeolites (Winograd, 1981, p. 1461) capable of sorbing nuclides. At Yucca Mountain, nonwelded tuffaceous beds of the Calico Hills would provide this underlying barrier, if the waste were to be placed in the welded tuff of the Topopah Springs member (Scott and others, 1983, p. 326).

Winograd (1981) proposed the second strategy for disposal of TRU wastes, which produce little heat, by burying them in unsaturated valley fill in Sedan Crater at the Nevada Test Site. He calculated conservatively that the potential downward vadose water velocities are on the order of 60 feet in 10,000 years. The sorptive properties of the valley fill itself and of underlying zeolitic tuffs would provide barriers to nuclide migration. Although suitable for waste with little or no thermal output, the second strategy presents problems for disposal of heat-producing waste. The second strategy will not be discussed further in this paper.

In summary, placing the waste in the unsaturated zone adds a new and very effective natural barrier-an environment that should remain nearly dry during the desired period of containment. Because water in the unsaturated zone would ultimately merge with water in the saturated zone, many, if not all, of the additional natural barriers that exist below in the saturated zone also pertain to the unsaturated zone. They are now, however, secondary barriers; the uncertainties known to be associated with assessing them (modeling of flow through fractures, defining the deep ground-water system, and determining effectiveness of sorption or other mechanisms of retardation) become correspondingly less significant.

\section{PURPOSE}

This paper will address specifically the consequences of employing the first strategy. While Yucca Mountain will occasionally be used as an example, the conclusions in this paper are intended to be generic rather than site specific. Scott and others (1983) have recently summarized the geology and the anticipated hydrologic conditions of the unsaturated zone at Yucca Mountain.

The paper explores how the differences between the saturated and the unsaturated zones could affect site characterization and design of a repository. Some of these differences are illustrated in figure 1, which summarizes graphically how a repository designed for the unsaturated zone would differ from one designed for the saturated zone. Although many of these differences appear advantageous, this should not be interpreted as meaning that a repository in one zone will necessarily perform better or be superior to a repository in the other zone. Meaningful comparisons of performance can be made only for specific candidate sites at an advanced stage of characterization. Choices of final sites will also require consideration of nongeologic, as well as geologic, factors. 


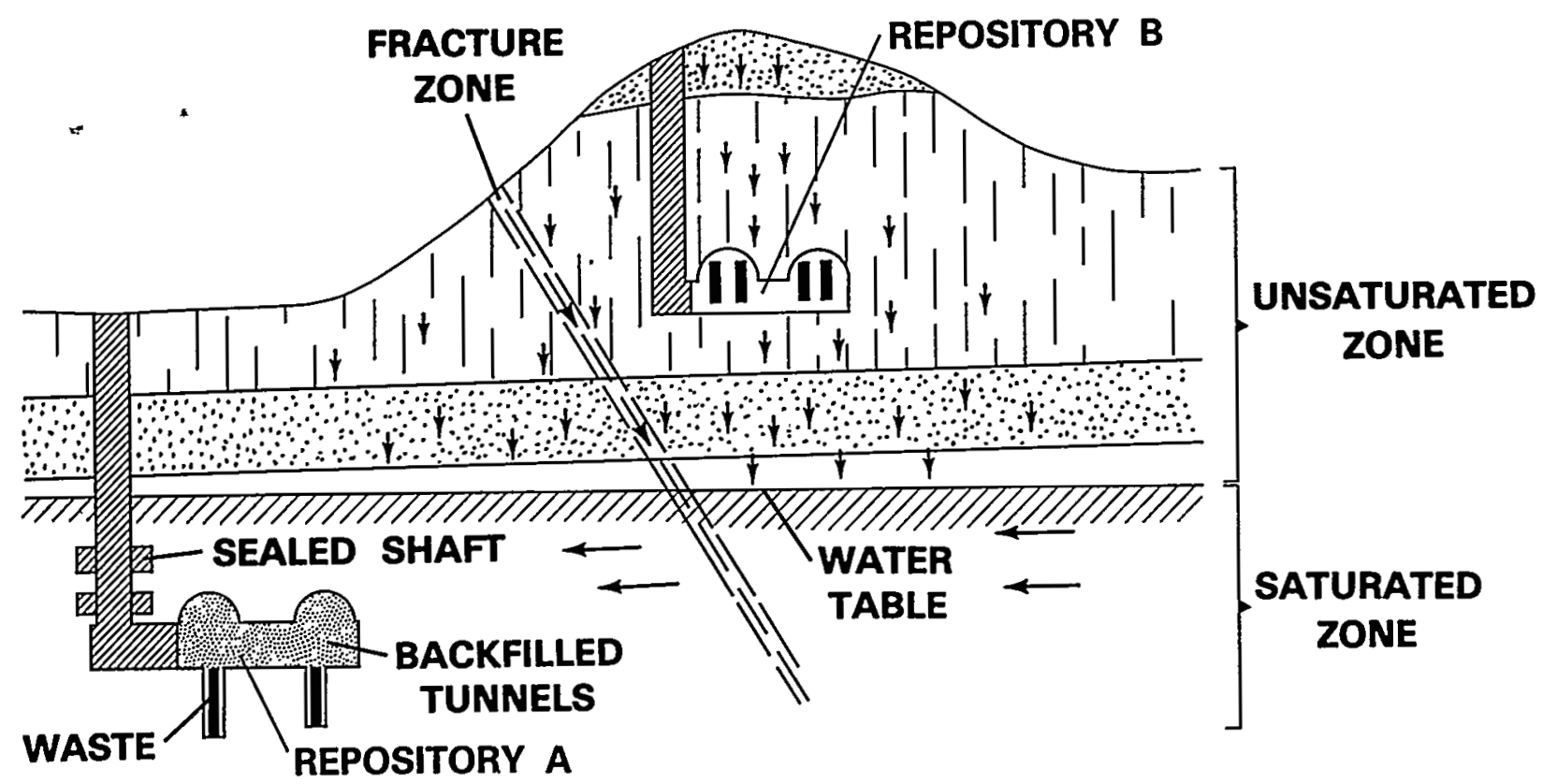

FIGURE 1.-Diagrammatic representation of a repository $(A)$ in the saturated zone and $(B)$ in the unsaturated zone. Direction of movement of water in both zones is shown by arrows. Water in the unsaturated zone originates as precipitation and moves downward to the water table where it joins water moving laterally from other recharge areas. In the unsaturated zone, relatively impermeable beds (dotted) slow the movement of water and may be nearly saturated. Those of high vertical permeability (vertical lines) allow rapid movement of the water to the next impermeable bed; thus only a small fraction of the available porosity of the highly permeable beds is filled by water, and tunnels in these beds would be nearly dry. Repository A requires relatively impermeable host rocks, carefully sealed shafts, backfilled tunnels, and leach-resistant waste packages to minimize the risk of transportation of nuclides by ground water. Repository $B$ is located in a highly permeable host rock to rapidly drain away any recharge that may reach the repository and thus keep the waste dry; carefully sealed shafts and backfilled tunnels are unnecessary. Any dissolved nuclides will move downward and encounter the sorptive minerals in the underlying bed of low permeability before reaching the water table. Above the water table, the fracture zone might intermittently conduct surface water downward during heavy precipitation but usually would be nearly dry. Below the water table, the same fracture zone would be continuously filled with water.

\section{PRINCIPAL DIFFERENCES ASSOCIATED WITH REPOSITORY LOCATION IN THE UNSATURATED ZONE}

The principal differences associated with repository location in the unsaturated zone will be grouped under the following categories: (1) site exploration and characterization, (2) predictability of performance, (3) waste package design, (4) repository design and sealing, and (5) monitoring of performance, retrieval of waste packages, and decommissioning. The principal new concerns associated with repository location in the unsaturated zone include (1) possible exhumation by natural processes, (2) possible future change to a wetter climate resulting in a major rise in the water table or a greatly increased flux of water in the unsaturated zone, (3) greater ease of exhumation of the repository by our descendants, and (4) possible release of gaseous fission products if spent fuel were the waste form.

\section{SITE EXPLORATION AND CHARACTERIZATION}

In the unsaturated zone, a proposed repository site could be explored from the surface by numerous drill holes. Conversely, potential sites in the saturated zone should be explored by as few drill holes from the surface as possible because of concerns as to whether such holes, if inadequately plugged, will serve as short circuits for groundwater flow. This is particularly true in salt, where openings might be rapidly enlarged by the ingress of fresh or brackish water. In the saturated zone, geophysical methods such as seismic profiling and electrical measurements must be relied upon heavily to establish continuity of rock formations and 
absence of unfavorable features. Most exploration of the subsurface of a candidate site in the saturated zone has to wait until an exploratory shaft has been completed and the proposed host rock can be explored by horizontal drill holes or tunnels.

Winograd (oral commun., 1982) has pointed out that, in the unsaturated zone, if the host rock already has a high vertical permeability, there is no particular reason to limit the number of drill holes from the surface. Thus the proposed repository could be explored, if necessary, like any ore body or coal bed, with drill holes every few hundred feet on a rectangular grid. Sealing of drill holes will be discussed under Repository Design, p. 11.

It is difficult to conceive of any geologic "surprises" that could present serious problems during site characterization in the unsaturated zone. Exploration of any repository site has the potential for uncovering previously unsuspected features such as fracture zones, faults, solution features, and other possible pathways for water to the repository horizon. Depending on their nature and extent, such features might even render a potential site unlicensable.

Winograd has pointed out (oral commun., 1982) that the most unfavorable feature that might be encountered in the unsaturated zone would be a large zone of perched water, where a relatively impermeable bed or zone has collected a large amount of descending water. Such features have been encountered at the Nevada Test Site but have largely drained in a matter of months (Thordarson, 1965; Ege and others, 1980). At the worst, a number of holes might have to be drilled to drain such a zone. Once drained, such a zone would no longer constitute a hazard. Any continuing flow would be relatively small. If the site were explored with a large number of drill holes, one would expect that at least some of these would penetrate any zones of perched water that might be present and would help to drain them. In this regard, numerous exploratory drill holes would actually be desirable to demonstrate that no such zone was present.

If previously unknown faults or fracture zones are encountered in the unsaturated zone during the characterization or construction phases of the repository, the faults or fracture zones should not constitute a serious problem because of the low average flux of water (Winograd, oral commun.,
1982). Below the water table, such features would be filled continuously with water from a virtually unlimited source; in the unsaturated zone, they would behave more like storm sewers (see fig. 1). At worst, such features might constitute a kind of "down spout" for surface drainage during unusual precipitation events. Consequently, they could almost certainly be handled by appropriate design of the repository drainage or, at the very worst, by sealing off tunnels that encountered them. Such a seal would need only to keep most of the water confined to the fracture zone during any precipitation events heavy enough to produce a temporary flow of water. There should be opportunity to evaluate the consequences of such precipitation events during the operational phase of the repository.

\section{PREDICTABILITY OF PERFORMANCE}

Predicting thermal-mechanical-hydrologic interactions would be reduced to predicting thermalmechanical interactions for a repository in the unsaturated zone. In the saturated zone, water at the level of a repository would probably be under a head of pressure roughly equivalent to the depth below the water table. The thermal load of a nuclear waste repository may induce new fractures and modify existing ones; near the waste, fractures might be closed initially by thermal stress but would tend to open on cooling. The problem of predicting the distribution, permeability, and extent of such fractures, the effect of the fractures on the rock strength, and the behavior of water in them becomes very complex because, as the water moves, it also transports heat. The ultimate objective is to avoid having thermally induced and existing natural fractures form a network that would greatly increase the access of ground water to and from the repository or that would result in a shortened flowpath to the accessible environment.

In the unsaturated zone, the interactions would be essentially thermal-mechanical. Hydrologic interactions would be minimal or absent because any water in the proximity of the repository during the thermal phase would be at pressures no greater than atmospheric. The water would simply evaporate and flow away from the waste (Geotechnical Engineers, Inc., 1979, p. 67; Evans and others, 1980). If the concentration of vapor became high enough, the vapor would recondense and accumulate in cooler rocks farther from the waste. The 
recondensed water could drain down through the repository wherever rock temperatures between the canisters were below $100^{\circ} \mathrm{C}$. Such zones, cooler than $100^{\circ} \mathrm{C}$, would increase in size as the repository cooled, but the immediate vicinity of each waste package would be the last to cool. Thus the thermal load would help to keep the waste package dry during the thermal phase of the repository. In contrast, water in fluid inclusions in salt tends to migrate toward the source of the heat, although recrystallization and flowage of the salt probably would keep the water confined to the repository. Movement of water into a repository will be discussed in the next section.

The breakdown of some sorbant minerals in the near-field may occur, depending on the rock temperatures attained, but this is a small price to pay. As long as such minerals are present between the repository and the water table, the minerals will provide a barrier to nuclide migration because any water that might come in contact with the waste would ultimately move essentially downward.

The direction of ground-water movement through a repository in the unsaturated zone and its environs is known, and the maximum amount that might reach the waste is readily bounded. In the saturated zone, the problem of determining the volume of ground water that might contact the waste, the water's subsequent path, and rate of flow is very complex. Klingsberg and Duguid $(1980$, p. 26) have summarized the problem as follows:

Repositories located below the water table can be expected to become saturated with ground water; the rate of incoming water will depend on the host rock permeability, the depth of the repository beneath the water table, the effectiveness of shaft and borehole sealing techniques and, for salt, the rate of repository self-sealing as a result of plastic flow. After the repository and associated shafts are saturated, ground-water flow through and in the immediate vicinity of the repository will be influenced by a complex coupling of: (1) the mechanical response of the host rock to repository construction; (2) the thermal pulse; and (3) the natural hydraulic gradients, permeabilities, and related factors that existed prior to repository construction.

In the unsaturated zone, the direction of water movement between the surface and the water table will be essentially downward. Below the water table, the movement will be controlled by the natural hydraulic gradients, permeabilities, and related factors. Geotechnical Engineers, Inc. (1979), reviewed the characteristics of the unsaturated zone, the mechanisms of unsaturated zone flow, and the geohydrology of four areas.
They found that, although the physics of unsaturated flow in soils and rock is not yet completely understood, under certain conditions, unsaturated flow can be so slow that analytic modeling of an unflawed repository is unnecessary to prove effective containment.

Except for possible extreme precipitation events (for example, a 10,000-year flood), the maximum amount of water that could pass through the repository over long periods of time is a fraction of the average future precipitation (on the order of a few percent) and is readily estimated since no other source of water is available. For example, assume that the rainfall is about 5 inches (12.7 centimeters) per year (a reasonable guess for Yucca Mountain). If 3 percent of this were to reach the subsurface and to drain vertically through the candidate horizon, the average amount of water reaching that horizon each year would correspond to a layer 0.15 inches (3.8 millimeters) deep. Even if the recharge from an unusual precipitation event corresponding to 10 times an entire year's average precipitation were somehow instantaneously transported to the repository horizon, we would still have a layer of water only 1.5 inches deep that would drain in a matter of hours or days because of the high fracture permeability.

Only a fraction of the water migrating downward through the repository would actually contact waste. The amount that might contact the waste can be readily estimated from geometric considerations by assuming that the waste intersects a quantity of the annual layer of recharge equivalent to the waste's horizontal cross sectional area. For example, assume that spent fuel from a boiling water reactor (BWR) is the waste form and that the fuel assemblies are simply placed in vertical holes. The horizontal cross section of a single fuel assembly that a vertically decending horizontal layer of water would encounter is about $14 \times 14$ centimeters in area (Majumdar and others, 1982, p. 144), or 196 square centimeters. If the layer of water averages 3.8 millimeters in thickness, the volume of water that would be intercepted by the cross section of the fuel assembly would be $\mathbf{7 5}$ milliliters per year. Alternatively, if the fuel assembly, which is about 4 meters in length, were placed so as to encounter the maximum amount of water, the assembly would lie horizontally with one edge upward, producing a cross section of 7,920 square centimeters $(14$ centimeters $\times 1.414 \times$ 400 centimeters). In this orientation, an average 
fuel assembly would intercept an average volume of water of about 3 liters per year, or about 40 times the volume of water it would encounter in a vertical position. If several assemblies were stacked one above another, this difference would be reduced accordingly.

Of course, any descending water will not actually pass downward as an evenly distributed sheet. Local differences in vertical permeability may cause some lateral movement, with water becoming more concentrated in some areas and diminished in others. However, over the horizontal area occupied by a repository, these differences should average out. Note also that the above estimates of water that would actually contact waste make no allowance for engineered barriers and drains aimed at reducing this contact. As mentioned previously, the heat generated by the waste also would tend to keep water away from the waste through evaporation and recondensation during the thermal pulse.

As mentioned previously, very young water has been encountered locally in the unsaturated zone; the presence of young water indicates a short downward ground-water transit time between the surface and the point of measurement (still in the unsaturated zone) for some of the water. If young water occurs locally in a few through-going fractures or fracture zones, its short transit time could give an erroneous impression of the repository's capability to contain nuclides. In such cases, calculations of ground-water transit time should take into account the relative volumes of young water and older water passing through the repository to obtain an average transit time. The effectiveness of drains in isolating any younger water from the waste may be a further consideration.

In the unsaturated zone, estimates of the average amount of water annually passing through a repository and of the fraction of this water actually contacting waste can be refined and verified by direct observation. Once underground workings are available, observations can be made of the actual amount of flow into these workings; such measurements could be continued over the entire operational phase if necessary. Similarly, observations can be made to determine the effectiveness of the drainage systems and other engineered barriers to reduce or to prevent contact of water with the waste. Thus, estimates of the amount of water that might reach the waste can ultimately be verified by actual experience and direct measurements over a period of decades.
In the saturated zone, direct measurements of the amount of water moving through and contacting waste in a sealed flooded repository can never be made. For a repository in salt, the amount of water moving through the repository should be negligible if the seals are adequate. For crystalline rocks, the amounts of water entering a repository during the operational stage can be measured, but this will be much more than would enter the same repository filled with water at the prevailing pressures of the surrounding ground water. Estimates of the amount of water contacting the waste will have to be based on the estimates of regional flow developed from measurements in wells surrounding the site and the physical properties of the rocks. Such estimates can never be verified by direct observations.

\section{WASTE PACKAGE DESIGN}

Spent fuel might be an adequate waste form; leach-resistant waste forms might be unnecessary. NRC 10 CFR Part 60 specifies that containment of nuclides within the engineered system will be substantially complete for a period of 1,000 years after permanent closure. Following this period, the release rate of any radionuclide shall not exceed 1 part in 100,000 per year of the inventory of that radionuclide calculated at 1,000 years after permanent closure. This does not apply to any radionuclide that is released at a rate of less than 0.1 percent of the calculated total annual release at 1,000 years after permanent closure.

The following calculations address the question of whether spent fuel might satisfy the $1 / 100,000$ release rate. They assume that, after 1,000 years of containment in a canister, the average fuel assembly in a repository filled with BWR spent fuel comes in direct contact annually with the amounts of water indicated in the preceding section; that is, the canister and engineered barriers provide no further protection. We will further assume that any water that does contact the fuel assembly will become fully saturated with the radionuclides in question; that is, we will consider solubility rather than leach rate to control dissolution.

In their review of waste package development, Dayal and others (1981, p. 8) state that:

It should be mentioned, however, that for the actinides and the rare earths, differences in leach rates for the various waste 
forms do not appear to be significant. *** It appears that the lack of variation in the leach rates observed for the actinide and tare earth elements is due to the known solubility constraints on their chemical behavior. Considering that the actinides predominate during the post-1000-year containment period, we believe that their release will be determined by their solubility behavior rather than the rate of waste form dissolution. Therefore, actinide release may not be continuous and controlled over a period of time but episodic, primarily determined by a shift in local saturation equilibrium resulting from changing repository conditions. Considering these factors, the validity of evaluating the $10^{-5} / \mathrm{yr}$ actinide-controlled release criterion using mainly fission product or rare earth or actinide leach rates based on short-term laboratory experiments is open to question.

Unfortunately there is much data on leach rates but relatively little on solubilities, especially under the oxidizing conditions that would prevail in the unsaturated zone. Therefore we will proceed by determining what concentrations of radionuclides in water would be acceptable with an annual release rate of $10^{-5}$ per year and comparing these "permissible" concentrations with the available data on solubilities of the actinides.

In table 1 , column $A$ shows the radiation in curies that would be emitted from the major radiation-producing elements of a 1,000-year-old BWR assembly; only those elements that individually would contribute at least 0.1 percent of the total radiation were included, and they account for 286.0 of the total of 287.3 curies, or 99.5 percent.
Column B indicates the amount of an element in grams present in the assembly after 1,000 years. Column C is $10^{-5}$ of that amount or what would be the "permissible release" annually under NRC 10 CFR Part 60. These "permissible releases" are then divided by the average annual amount of water that would encounter a vertical fuel assembly (75 milliliters per year) or a horizontal assembly (3 liters per year), as calculated in the preceding section (see p. 7,8), to produce columns $\mathrm{D}$ and $\mathrm{E}$, respectively. These represent the hypothetical concentrations that would be needed if the "permissible release" were to be transported in the water encountering the fuel assembly.

Column F summarizes the solubility data of Ogard and others (1981) and National Academy of Sciences (1983). Ogard and others performed leaching experiments on spent fuel and compared their results with calculated solubilities of various studies. They found that the ratios of europium, cerium, americium, and plutonium to uranium in the leachants under oxidizing conditions were very much lower than the calculated ratios in the original spent fuel. They concluded that "These large differences in the ratios can occur if europium, cerium, americium, and plutonium are at their solubility limits and precipitate as some form of hydrous oxide as the $\mathrm{UO}_{2}$ matrix continued to dissolve with time." Their experimental

TABLE 1.-Hypothetical concentrations of "permissible" releases of radionuclides and their solubilities (1000-year-old BWR fuel assembly)

\begin{tabular}{|c|c|c|c|c|c|c|}
\hline Element & $\begin{array}{c}A^{2} \\
\text { Radiation } \\
\text { (curies) }\end{array}$ & $\begin{array}{c}\text { B' } \\
\text { Mass } \\
\text { (grams) }\end{array}$ & $\begin{array}{c}\mathbf{C}^{2} \\
\text { "Permissible release" } \\
\text { (grams per year) }\end{array}$ & $\begin{array}{c}\text { D } \\
\text { Concentration } \\
\text { (75 milliliters } \mathrm{H}_{2} \mathrm{O} \text { per year) } \\
\text { (grams per liter) }\end{array}$ & $\begin{array}{c}E \\
\text { Concentration } \\
\text { (3.0 liters } \mathrm{H}_{2} \mathrm{O} \text { per year) } \\
\text { (grams per liter) }\end{array}$ & $\begin{array}{c}\text { F } \\
\text { Solubility measured', } \\
\text { calculated ( ) or } \\
\text { compiled ( })^{4} \\
\text { (grams per liter) }\end{array}$ \\
\hline $\mathrm{Zr}=$ & 0.4 & 615.9 & $6.2 \times 10^{-3}$ & $8.3 \times 10^{-2}$ & $2.0 \times 10^{-3}$ & {$\left[10^{-7}-10^{-9}\right]$} \\
\hline $\mathrm{Nb}-$ & .4 & .1 & $8.0 \times 10^{-7}$ & $1.1 \times 10^{-5}$ & $2.7 \times 10^{-7}$ & $?$ \\
\hline Tc $\longrightarrow$ & 2.0 & 119.9 & $12 \times 10^{-3}$ & $1.6 \times 10^{-2}$ & $4.0 \times 10^{-3}$ & [High, $>10^{-5}$ ] \\
\hline $\mathrm{U}$ & .4 & $176,500.0$ & 1.8 & $2.4 \times 10^{-1}$ & $5.9 \times 10^{-1}$ & $\begin{array}{c}>2.1 \times 10^{-7} \\
\left(10^{-4}-10^{-5}\right)\end{array}$ \\
\hline $\mathrm{Np}$ & 2.2 & 224.4 & $2.2 \times 10^{-3}$ & $3.0 \times 10^{-2}$ & $7.5 \times 10^{-4}$ & {$\left[10^{-4}-10^{-5}\right]$} \\
\hline $\mathrm{Pu}-$ & 130.4 & $1,280.0$ & $1.3 \times 10^{-2}$ & $1.7 \times 10^{-1}$ & $4.3 \times 10^{-3}$ & $\begin{array}{c}1.3 \times 10^{-9} \\
\left(10^{-6}-10^{-10}\right)\end{array}$ \\
\hline Am - & 150.2 & 53.9 & $5.4 \times 10^{-4}$ & $7.2 \times 10^{-3}$ & $1.8 \times 10^{-4}$ & $\begin{array}{r}{\left[\text { High, }>10^{-5}\right]} \\
>2.1 \times 10^{-10} \\
{\left[10^{-8}-10^{-11}\right]}\end{array}$ \\
\hline
\end{tabular}

'From Majumdar and others (1982, p. 146-160).

"Values in column $\mathrm{C}$ equal those of $\mathrm{B} \times 10^{-3}$.

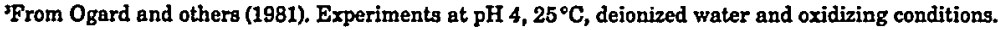

"Compiled by Krauskopf for National Academy of Sciences (1983, p. 147). 
solubility limits are for $25^{\circ} \mathrm{C}$, oxidizing conditions $\left(\mathrm{CO}_{2}\right.$-free air bubbled through leachant), and a $\mathrm{pH}$ of 4.

The calculated solubilities in column $F$ compiled by Kranskopf for National Academy of Sciences (1983) are in part from published experimental work and in part calculated from thermochemical data. Solubilities higher than $10 \mathrm{ppb}\left(10^{-5}\right.$ grams per liter) were simply designated "high" in that report because it was felt that they could not be an effective control of radionuclide concentration. Higher solubilities than $10 \mathrm{ppb}$ could still provide such control in the unsaturated zone because the limited mass of water contacting the waste provides an additional control.

The hypothetical concentrations of column $\mathrm{D}$ for a vertical fuel element and $E$ for a horizontal one can be compared with the solubilities of column F, to see whether the release rate of $10^{-5}$ is likely to be met for spent fuel. Although the solubility data is inadequate, there is no case where the solubilities clearly exceed the hypothetical permissible concentrations. Even for elements with solubilities given as "high," $>10^{-5}$, the permissible concentrations are appreciably higher than $10^{-5}$. Tc is the most questionable of these but its permissible concentrations are $10^{-2}$ to $10^{-3}$.

The foregoing discussion of possible releases has not addressed the question of estimating the future concentrations of nuclides that might occur in the ground water down gradient from the repository site. For this, a number of other site specific factors would have to be evaluated. Ground-water traveltime and delay of nuclides due to sorption must be considered both in the unsaturated zone and in the saturated zone. In addition there would be two dilutions: (1) the water passing through the repository and actually contacting the waste would be diluted by the rest of the water passing through the repository but not contacting the waste; (2) the sum of the above would become diluted further at the water table by laterally moving ground water. For example, if canisters (0.6-meter diameter) were emplaced vertically, 3 meters apart in drifts 15 meters apart (as simulated in the Climax granite spent-fuel-storage test), the first dilution factor would be about 150 on the basis of geometry alone; if emplaced horizontally, about 15. According to Winograd (1981), the second dilution could be from one to several orders of magnitude at Yucca Flat.

Canister design requirements for repositories in the unsaturated zone will be very different from those required for containment in the saturated zone. In the saturated zone, canister design must assume immersion in ground water, in some cases under a significant head of pressure. For example, Atomic Energy of Canada Limited has designed, tested, and modeled the deformation and collapse of a "stressed shell" container designed with sufficient shell thickness to withstand the hydrostatic pressure within a 1,000-meter-deep repository postulated to have flooded with ground water (Crosthwaite and others, 1980). The canister was designed for boundary conditions of $150^{\circ} \mathrm{C}$ and a hydrostatic pressure of 9.8 megapascals $(1,422$ pounds per square inch). Stainless steel with a shell thickness of 49.8 millimeters (1.96 inches) was used for the prototype. In the case of salt, the canisters probably would be isolated from the ground-water systems but would be near lithostatic pressures due to flowage of the salt. The waste package might be locally surrounded by brine due to migration of brine-filled inclusions up the temperature gradient. Ground-water oxidiation states in the saturated zone would probably be reducing, although a number of occurrences of deep water with dissolved oxygen recently have been described by Winograd and Robertson (1982).

In the unsaturated zone, pressure on the canisters would be only that of the atmosphere and perhaps that imposed by any backfill materials. Any contact of the canisters with water would be intermittent or sporadic, possibly with alternating wet and dry periods. Locally, a few canisters might be wetted frequently, others occasionally, and others still would remain entirely dry. Heat generated by the waste would tend to keep liquid water at a distance (Evans and others, 1983, p. 177) at least until the temperature of the surrounding rock falls below $100^{\circ} \mathrm{C}$. The water would tend to be in equilibrium with the atmosphere; hence, it would probably be oxidizing.

For steel or iron canisters, intermittent wetting in aerated water in the unsaturated zone would present a relatively corrosive environment compared to total immersion in nonaerated waters in the saturated zone. However, the effects of partial immersion and exposure to stream for decades during resaturation of a repository in the saturated zone also could be severe (National Academy of Sciences, 1983, p. 85). In the unsaturated zone, the canisters would never become even partly immersed. The average mass of water that might 
contact them annually is limited and can be estimated; this-may allow estimation of the rate of corrosion.

Because the canisters in the unsaturated zone will be subject to dripping or downward trickling ground water rather than immersion, a simple overpack over the canister should provide adequate protection. Such an overpack might be made of titanium or even ceramic. It could even be open at the bottom, since steam or water vapor has very little transporting capacity.

In visualizing the saturated and unsaturated environments, the hydrologic conditions surrounding the canisters in crystalline rocks in the saturated zone may be considered somewhat analogous to locating the canisters in sediments at the bottom of a lake (the ground water) that is several hundred to perhaps 2,000 or 3,000 feet deep. In the case of salt, the canisters are under the lake but isolated from it by the essentially impermeable salt; they would be under lithostatic pressure and perhaps surrounded locally by brine. Hydrologic conditions in the unsaturated zone are more analogous to placing the canisters on the surface under gravel or broken rock in an area with extremely low annual rainfall but perhaps high humidity.

\section{REPOSITORY DESIGN AND SEALING}

Emplacement of waste should allow for drainage. If water gained access to a repository in the saturated zone, the repository would become flooded, and the waste would be immersed in water. Consequently, it must be assumed that all nonsalt repositories in the saturated zone will eventually be filled with water.

In the unsaturated zone, flooding would be virtually impossible because of the low flux of water and high fracture permeability of the host rock; any water reaching the waste would rapidly drain off. The repository would be designed to minimize possible contact of water with waste package. For example, Winograd (oral commun., 1982) has suggested that canisters could be placed on the floor of the tunnel with flanking ditches to remove water. Alternatively, if canisters were emplaced in vertical holes, the bottom portion of each hole could be filled with coarse material to provide a dry well and to keep the hole drained of water (fig. 2A). The holes could be lined or grouted and col- lared to reduce the amount of water that might enter from fractures along the sides of the holes. The canister could rest on a pedestal in the hole (E-an Zen, oral commun., 1983) or on the bottom of the hole above a smaller diameter hole through which water could drain (D. E. White, oral commun., 1983). Alternatively, Winograd suggests that the canisters could be emplaced in subhorizontal holes in the sides of the tunnel; the holes could slope slightly upward to provide drainage into the drift so that water would not accumulate in them (fig. 2B).

Sealing shafts and boreholes tightly to inhibit water movement is unnecessary and probably undesirable in the unsaturated zone. In the saturated zone, boreholes and shafts need to be carefully sealed so that they do not become fuiture conduits for ground water and radionuclide migration. This is especially important in repositories located in salt because of the high solubility of the host rock. The research being done on this problem has been summarized by D'Appolonia Consulting Engineers $(1980,1981)$. Wendall Marine (in D'Appolonia, 1980, p. 15-17) identified four issues involved in field tests of seals-the damaged zone around the hole (or shaft) caused by drilling the hole, the interface between the plug and the rock, the plug material and the permeability of the plug itself, and quality assurance requirements of plug emplacement. He pointed out that "monitoring actual plugs in a repository is a particularly thorny issue because, in the large part, the procedure will be developed and quality assured, and then from that point on it will largely be a matter of faith that the plug is working. To attempt to put monitoring devices in a plug may itself destroy plug integrity." Ellison and others (1981) provided some schematic designs that give a clear idea of how sealing of tunnels and shafts might be accomplished in bedded salt. At various points, the shaft or tunnel would be enlarged by removing additional material comprising the disturbed zone. The enlarged portions would be filled with concrete, bentonite, or other especially chosen material and would serve as seals or bulkheads; the rest of the tunnel or shaft would be filled with backfill. Roy (1981) reviewed the seal materials being considered and pointed out that such materials should be mechanically adequate, bond well to the host rock, be able to resist permeation of fluids particularly in the interfacial zone, be stable and chemically durable, be compatible with the surrounding rock 

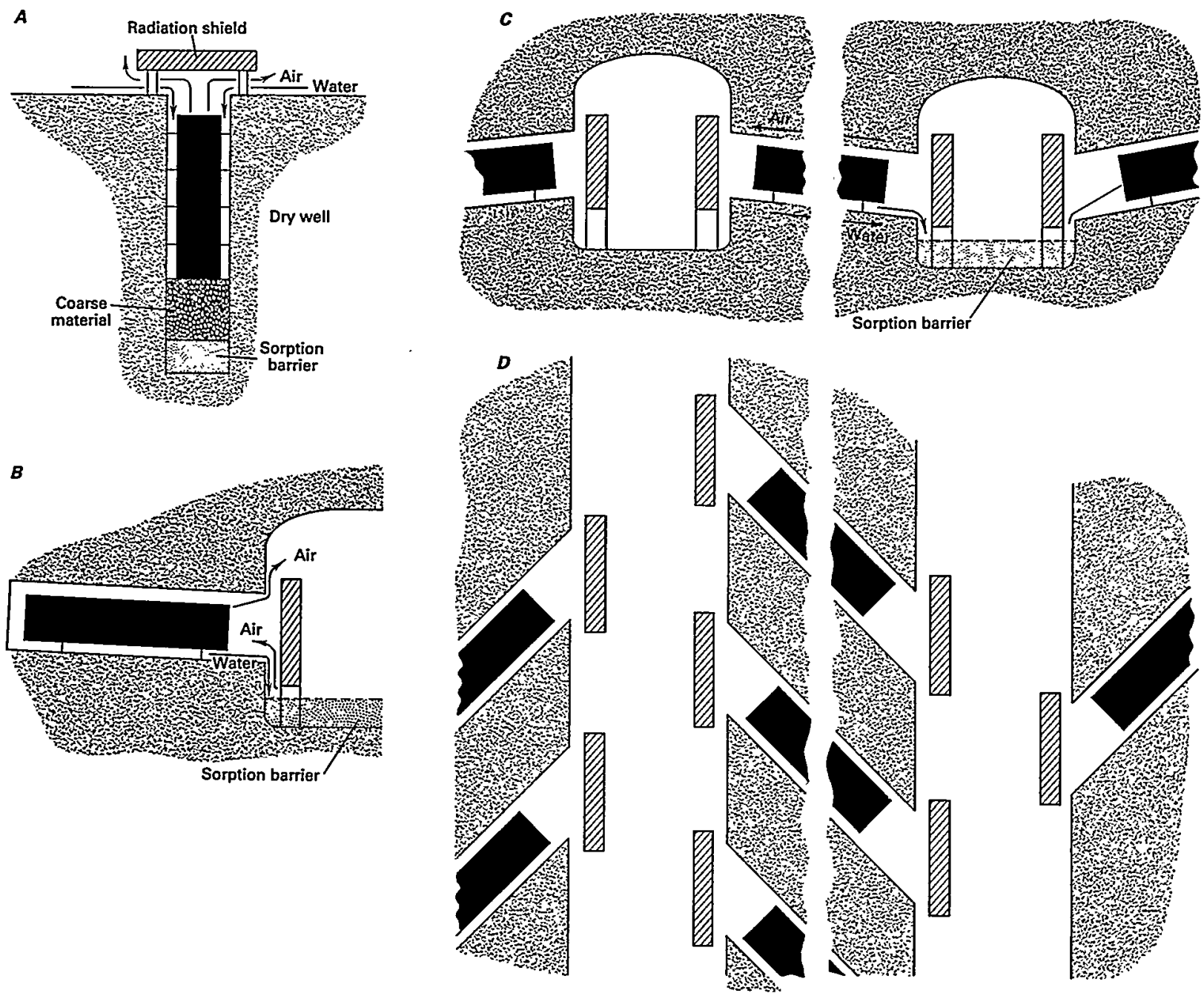

FIGURE 2.-Some ways of emplacing canisters in tunnels in the unsaturated zone to allow both circulation of air to remove heat and to allow drainage of water. $A$, Canister is emplaced in vertical hole with dry well at bottom (Winograd, oral commun., 1982) and clearance between floor and radiation shielding to allow circulation of air. $B$, Emplacement of canister in subhorizontal hole (Winograd, oral commun., 1982). C, Emplacement of canisters in holes between tunnels to allow air to move upwards and water to drain downwards. $D$, Plan view of $C$ showing angling of holes to reduce width of the tunnels. In all diagrams, canisters are solid, and shields have diagonal shading.

and ground water, and be resistant to destructive expansion and contraction and to nuclide transport. The above properties and functions are also important over the long time period of repository isolation.

In the unsaturated zone, shafts and boreholes would have an entirely different relation to a repository. Shafts would increase the amount of water moving through the repository only if they diverted a significant amount of surface runoff into the subsurface. Thus they should not be located in the bottom of gullies or washes, which focus runoff; ideally they should be located on drainage divides or hilltops, although these would change with time. The focus of any sealing effort should be near the top of the shaft to prevent ingress of runoff.

The average amount of water passing through the repository would be determined by the local recharge; as long as the upper part of shafts or holes were sealed, they would make no additional contribution to this flux, although dipping fractures intersecting a shaft would channel flow into it. If the lower parts of the shafts (or holes) were 
sealed so as to be less permeable than the fractured host rock, the local effect on the downwardmoving water would be to divert it from the shaft into the surrounding rock where it could not be controlled. On the other hand, if the lower part of the shafts were filled with coarse material, any water migrating into them would tend to stay in the shafts. The shafts could be extended a short distance below the repository horizon so that any water that might drain into them from the host rock would bypass the repository. Drainage from the tunnels also could be led into the shafts as is commonly done in mines where water has to be pumped out. In this case, however, pumping would be unnecessary.

In the saturated zone, the host rock is relatively impermeable, and the objective is to obtain a seal that, if not of comparable permeability (which may be nearly impossible to achieve), at least will inhibit transport of radionuclides to the same degree as the undisturbed units of rock through which the shafts or boreholes pass. The two objectives of minimizing movement of water and inhibiting transport of radionuclides can both be achieved by seals of low permeability.

In the unsaturated zone, it is desirable to have high vertical permeability above, at, and immediately below the repository level to minimize contact of water with the waste. Further below the repository, low permeability is desirable to maximize traveltime and to allow sorption of any nuclides that may have been picked up. Because the movement of ground water is only downward, the part of the shaft above the repository horizon is not a possible route to the accessible environment (except for gaseous radionuclides). Thus, for nuclide migration in ground water, we need be concerned only with the portion of the shaft that is below the repository horizon. For this portion, seals would not be needed because the shaft would terminate a short distance below the repository level.

Similar considerations apply to drill holes, though on a much smaller scale. Even if drill holes were left unsealed, the amount of surface water draining into them would probably be negligible because of their small size. Wherever such holes were encountered in the repository, it would be a simple matter to avoid putting waste in their immediate vicinity, as well as to arrange for drainage of any water from them.

In summary, the question of sealing shafts and boreholes is very different in the unsaturated zone, and the goals of such work in the saturated zone do not apply.

Heat generated by wastes in a repository in the unsaturated zone could be removed by multiple ventilation shafts. In a repository in the saturated zone, the number of shafts (or tunnels to the surface) probably would be kept to a minimum because of the concern over sealing the shafts adequately. Consequently, all the waste-generated heat removed to keep the workings at reasonable temperatures for men and equipment must escape through a limited number of shafts. If all of the repository workings were kept accessible (not backfilled) during the period of retrievability, a considerable volume of air would have to be moved through these shafts.

In the unsaturated zone, additional shafts for ventilation would not compromise the repository's performance because sealing shafts in the unsaturated zone is much simpler and of less consequence than in the saturated zone. Because of the past emphasis on avoiding unnecessary penetration of the repository horizon, even by drill holes, additional shafts may seem revolutionary but should be carefully considered because the potential benefits are considerable. Removing the heat through ventilation essentially removes or greatly reduces the problem of the thermal load imposed on the repository in its early phase. This reduction of the thermal load has major implications for retrievability (see p. 16), amount of waste per volume of repository, and predictability of performance. Removing the heat by ventilation also would carry off water vapor and thus further help to keep the repository dry during the operational period; the drawing of large quantities of warm, dry desert air through the repository should produce even drier conditions than those naturally present. Multiple shafts also would increase the safety of personnel during the operating period by providing alternate sources of ventilation and escape routes in case of fire or accidents.

Passive ventilation systems could be employed in repositories in the unsaturated zone. Hammond (1979) proposed a concept of long-term monitored retrievable storage in shallow tunnels by using passive ventilation. He envisioned a tunnel or adit opening onto the side of a mountain with a series of ventilation shafts to the surface, acting as chimneys. The heat given off by the stored canisters would provide continuous ventilation because 
of thermal convection; hot air, being lighter, would rise up the vertical shafts, drawing denser cooler air in through the mouth of the tunnel. The waste canisters would simply be stacked in movable storage racks by remote-handling equipment. Container performance would be monitored by sealing a readily detectable gas between an inner and outer container (a method used in the present experiment in storing waste canisters in granite at the Climax Stock, Nevada Test Site). The tunnel would slope to drain any water out its mouth. Although Hammond said nothing about the water table, he specifically cited the extensive tunnel systems in the unsaturated zone developed for weapons testing at the Nevada Test Site as an example of such a tunnel system ready for use.

Although Hammond's proposed ventilation system draws the cooler air in through the mouth of a tunnel, the same basic concept probably could be applied to a repository connected to the surface only by shafts. The only difference would be that, instead of entering at the mouth of a tunnel, cooler air would enter through a vertical shaft. As in Hammond's concept, the thermal expansion of the air heated by the waste would provide the updraft. Tunnels could be inclined as needed to both encourage the upward movement of warmer air and to promote efficient drainage.

Although Hammond's concept would be acceptable for interim storage, the stability of the tunnels probably could not be assured for the thousands of years desired for permanent disposal. Thus, canisters could not be left in the middle of tunnels where a large rockfall might rupture them. Schronhorst and others (1981) have described conceptual designs for a self-shielded package that could be transported and emplaced with little or no additional shielding; the packages simply could be placed on the floor of the tunnel. Because such canisters would involve a considerable thickness of steel or cast iron, they might be sufficiently strong to withstand most rockfalls. If not, the tunnels might be filled later with coarse backfill when retrievability was no longer of interest. Damage to canisters also could be avoided by emplacing them in holes drilled in the floor or wall as shown in fig. $2 A$ and $B$. The hole could be made sufficiently larger than the canister to allow air circulation. Radiation shielding could be placed across the access opening in such a way as to allow air to enter and leave the hole. This would have the considerable advantage of keeping the tunnels accessible to men instead of only to remote-controlled equipment, as in Hammond's concept.

I have suggested a slightly more elaborate system in figure $2 C$ and $D$. The holes containing the canisters would be drilled entirely through from one tunnel to the next and would tilt at a low angle. This would allow any water to drain downhill into the lower tunnel; at the same time, air would enter from that tunnel, become heated, and move uphill to the upper tunnel. Thus a ventilation system could be designed with alternating cooler and warmer tunnels at slightly different levels. As shown in figure $2 D$, the holes could be drilled at an angle to the direction of the tunnels if one desired to keep the width of the tunnels through which the waste is transported (presumably the cooler tunnels) to a minimum. Equipment for emplacing the waste would not have to be as sturdy as that required to raise and lower the canisters vertically (fig. $2 A$ ) because the canisters would be slid up (or down) a shallow incline. Canisters could have cooling fins and could rest on rails to avoid contact with the bottom of the emplacement hole where water might drain. The hole itself could be lined with a sleeve to divert any water that might tricklein through cracks and to maintain ease of emplacement.

In addition to economy of operation, a ventilation system that is passive or largely passive would have the advantage of continuing to function in the event of a disruption of power.

With increased ventilation, more waste could be emplaced in the same size repository. As pointed out by Hammond (1979), air cooling of a repository provides an additional benefit. An air-cooled. repository does not have to be designed to bear the load of thermally induced stresses that the waste would place on a repository if the waste were buried in backfill or snugly emplaced in the walls or floor. Consequently, more waste could be emplaced in the same volume of repository since the thermal loading imposed on the host rock is the main factor that determines the spacing of the canisters. With the reduced thermal loading imposed on the rocks, multilevel repositories, which have been considered from time to time in the past, could be used. Waste might be stored first in shallower levels with better ventilation and moved to lower levels for final storage.

In the unsaturated zone, tunnels need not be filled with backfill. Backfill apparently is required for a repository in the saturated zone. The draft of 
NRC 10 CFR Part 60 discusses backfill under the heading "Engineered Barrier." The draft states that the backfill is to serve the following four functions: provide a barrier to ground-water movement, reduce creep deformation that might adversely affect waste package performance or the local hydrologic system, reduce and control ground-water movement within the underground facility, and retard radionuclide migration.

What functions, if any, should backfill provide in the unsaturated zone? Its role would be the opposite of that in the saturated zone; that is, it should allow ground water to drain readily, rather than serve as a barrier to it and possibly cause local ponding (see p. 29-33). The most permeable tunnel would be one with no backfill at all.

If the rock is sufficiently strong or can be reinforced so that tunnels will remain structurally intact during the operational period, backfill should not be necessary. Fracturing and perhaps ultimate collapse of the tunnels due to lack of support would clearly increase the local permeability. If backfill should be deemed necessary to prevent collapse of the mine workings or protect the integrity of the canisters, Winograd (oral commun., 1982) has suggested that the backfill should be a relatively permeable material, such as cobble-sized rock fragments, to allow drainage to continue. If backfill is desired to retard radionuclide migration, it would be effective in doing so only as long as it was at or below the level of canisters since any contaminated water will move downward. Thus sorptive backfill could be placed for this purpose in the bottom portion of the tunnel if the canisters were emplaced in the walls (as in fig. $2 B$ and $C$ ). The rest of the tunnel could remain open for access. If the waste were emplaced in vertical holes, any backfill to adsorb nuclides would have to be at the bottom of the hole to be effective (as in fig. $2 A$ ).

\section{MONITORING, RETRIEVAL, AND DECOMMISSIONING}

In the saturated zone, a repository in salt probably could not be kept completely accessible during the whole of the operational period; creep of the salt would require backfilling before closure became too advanced. In crystalline rock, backfilling of the tunnels could be deferred but would be required eventually. In the unsaturated zone, backfill probably could be deferred or omitted entirely.

Wherever backfilling can be omitted or deferred, monitoring the performance of the repository and the waste packages is much easier. If part of a repository must be backfilled during the operational phase, the problem of monitoring the repository performance is greatly increased. Any sensing devices placed in the backfilled tunnels to monitor temperatures, radiation, water, and so on, could not be replaced if they should fail. Since monitoring would take place over a matter of decades, some instrument failures would seem inevitable. If failures of some waste packages were detected in the backfilled portion, there would be no means of retrieving the packages to determine the cause without mining out the backfill first. Any monitoring that required direct observations or equipment requiring access would have to be limited to portions of the repository kept open for such purposes.

If all the repository workings could be kept accessible during the operational period, monitoring the performance of the entire repository could be done by direct observation and measurement. Remote monitoring devices would be unnecessary, and any monitoring instruments that fail could readily be replaced. Individual canisters would be continuously accessible for examination for any deviations from expected performance. For a repository in the unsaturated zone, the amount of water passing through the repository could be observed and measured over the repository's operational life. Any major connections with the surface, such as shafts or fracture zones, could be monitored thoroughly to see if the desired drainage was being achieved, especially during unusual precipitation events.

Without backfill, retrieval of waste is much easier. If a problem were encountered that had not been foreseen or if reprocessing of buried spent fuel were desired, the canisters could be readily removed at low cost. This would be far less complicated than attempting to do the same thing in a repository where emplaced backfill would first have to be mined out. In a backfilled repository, canisters might be wedged in the holes because of the backfill and rock detritus from collapse or spalling of the walls of the hole. Determining whether individual canisters have been breached or have otherwise failed might be difficult, and the canisters might have to be mined out, along with 
contaminated rock (Kaiser Engineers, Inc., 1980, p. 101-107). All of this might have to be carried out in an underground environment that has been heated well above the temperature that existed when the original repository was mined. Because backfilling is not necessary in repositories located in the unsaturated zone and could be deferred in those in saturated crystalline rocks, these difficulties may be avoided, and waste retrieval may be much simplier than in salt.

Decommissioning a repository in the unsaturated zone would be relatively simple with no special sealing required; even abrupt abandonment of the repository would not affect the performance appreciably. Final decommissioning could be accomplished primarily by simply filling with coarse material all access shafts or tunnels connected to the surface. Backfilling the storage tunnels might not be necessary since we wish to promote drainage rather than slow it. The primary questions would be (1) whether ultimate collapse of the tunnels would result in subsidence at the surface and diversion of surface runoff into the repository and (2) whether backfill is needed to protect the canisters from rupture that might occur as a result of tunnel collapse. Sealing access openings to repositories in the unsaturated zone would be simple, compared to the sealing of openings to repositories in the saturated zone; failure of such seals would be of no particular consequence. Openings would be sealed primarily to keep surface runoff and people out of the repository.

Because decommissioning is relatively simple, it could be readily deferred as long as desired to provide permanently retrievable disposal. This might be desirable to assure safe performance, remove heat through ventilation, or maintain the reprocessing option. In fact, except for the need to keep people from entering the repository, a repository in the unsaturated zone abandoned during the operational period because of some overwhelming catastrophe such as nuclear war would present only a little more hazard to the natural environment than if it were completely sealed. Written warnings to future generations could be placed in the repository passageways during the operational period. A repository below the water table, however, could not be deserted so inconsequentially because abandoned shafts might provide a short cut for nuclide transport by ground water.

\section{PRINCIPAL CONCERNS ASSOCIATED WITH REPOSITORY LOCATION , IN THE UNSATURATED ZONE}

The preceding discussions have shown that many of the concerns and technical problems associated with locating a repository in the saturated zone become much less important when repositories are located in the unsaturated zone. Conversely, are there any concerns or possible problems that are minor for repositories located in the saturated zone that become of major significance in the unsaturated zone? Winograd (1981) identified four major concerns or possibilities that would have to be addressed if nuclear waste were placed in the unsaturated zone: (1) exhumation by natural processes (erosion, tectonism, or meteorite impact), (2) change to a wetter climate resulting in a major rise in the water table or greatly increased flux of water in the unsaturated zone, (3) exhumation by our descendants, and (4) possible release of gaseous fission products.

\section{EXHUMATION BY NATURAL PROCESSES}

The possibility of exhumation by natural processes does not appear to be a serious problem for a mined repository. Winograd demonstrated that the possibility of exhumation by erosion, tectonism, or meteorite impact should not be a serious concern for relatively shallow burial of TRU wastes at Yucca Flat; in this paper we are considering much deeper burial in a mined geologic repository. Draft NRC 10 CFR Part 60 specifies a minimum depth of 300 meters (984 feet) from the ground surface; the water table at Yucca Mountain in well G-1 was at an elevation of approximately 2,455 feet (Spengler and others, 1981), and the land surface at the proposed site is all above 4,100 feet. Thus the acceptable depth for a repository at Yucca Mountain in the unsaturated zone would lie between about 1,500 and 1,000 feet (elevations of 2,600 and 3,100 feet). By contrast, the depth of a repository in the saturated zone is limited only by factors such as rock strength, in situ stress, and temperature. 


\section{FUTURE CHANGE TO WETTER CLIMATE}

Increased precipitation will, of course, increase the flux through the repository and may cause a rise in the water table. In addition, the increased flux could produce local perched water tables and increased lateral movement above the more impermeable zones. However, the consequences of an increase in precipitation must be addressed on a site by site basis.

Winograd (1981) reviewed the evidence for past rises of the water table at Yucca Flat, NTS, during the Pleistocene when wetter climates prevailed. Winograd and Doty (1980) studied past deposits of tufa formed by springs during the Pleistocene and concluded that the water table probably did not rise more than 30 meters beneath Frenchmen Flat. Even if the water table under Yucca Mountain were to rise by several times the amount estimated for Yucca Flat, ample range of depth would still exist between the water table and the 300-meter minimum depth requirement. Winograd also reviewed the evidence for wetter climatic conditions during the Pleistocene. Conditions were clearly wetter and cooler, but semiarid conditions must have existed on the valley floors. Annual precipitation was probably no more than 50 percent higher during wetter Pleistocene climates. Because the present annual precipitation is probably on the order of 5 inches per year at Yucca Mountain, a 50-percent increase does not represent a very great amount of water. Most of this would be lost as runoff and through evapotranspiration, which would increase along with the vegetation.

A repository in the saturated zone will be much less likely to be adversely affected by changes in climate. Increased precipitation and rise of the water table could result in some increase in hydrostatic pressures, shortening of traveltimes, or changes in flow paths, but these usually would be of minor consequence.

\section{EXHUMATION BY OUR UNINFORMED DESCENDANTS}

A future civilization, seeking potable water, might inadvertently penetrate the repository with drill holes. At the Nevada Test Site, however, no water resource is present in the unsaturated zone; the target of such wells would have to be the saturated zone below the repository. Because of the relatively low flux in the unsaturated zone, such drill holes should have virtually no effect on the performance of the repository.

A future civilization might wish to reopen the repository out of curiosity or the hope of obtaining something of value. Such a civilization still would be faced with the problem of gaining access to the repository; that is, removing the fill materials from the shafts (and tunnels if backfilled or collapsed).

Even if the repository were reopened, appreciably more ground water is not likely to come in contact with the canisters because of the dry climate and the low flux of ground water in the unsaturated zone. In addition, the relatively impermeable rocks containing sorptive minerals that underlie the repository horizon and the traveltime of the ground water in the saturated zone would serve as barriers.

The waste packages could be dragged to the surface and used in some environmentally deleterious manner that we cannot foresee. This problem exists for any repository, but repositories in the unsaturated zone might present future intruders with an easier task. Intruders would not have to pump out any water from a repository in the unsaturated zone, and such a repository probably would be at a shallower depth than one in the saturated zone. Ease of intrusion is an unfortunate corollary of ease of retrieval.

The problem of warning future generations was addressed by Cameron (1981) who discussed the type of warnings that could be left on the basis of the kind of information that has been passed on versus the kind that has been lost from past civilizations. He concluded that we can assume that future generations will be able to decipher a warning message left at a repository. Weitzburg (1982) and Kaplan (1982) arrived at similar conclusions.

\section{POSSIBLE FUTURE RELEASE OF GASEOUS FISSION PRODUCTS IF SPENT FUEL IS A WASTE FORM}

Spent fuel contains three major gaseous fission products: krypton-85, carbon-14, and iodine-129. These represent three quite different problems 
because of their differing chemical behaviors and half-lives. Krypton-85 has a half-life of 10.6 years and, being a noble gas, remains uncombined with other elements. Evans and others (1980, p. 76) note that (for krypton-85 removed and concentrated from reprocessed waste) "Engineered storage facilities would be adequate permanent storage of krypton-85 since the krypton will have sufficiently decayed in about 100 years." Thus krypton-85 presents a hazard mainly during the operational period of the repository, if canisters should begin to leak. Krypton-85 could also provide a built-in leak detection system (D. E. White, oral commun., 1983).

Carbon-14 has a half-life of about 5,700 years and is a gas if combined with oxygen $\left(\mathrm{CO}_{2}\right.$ and $\left.\mathrm{CO}\right)$. Thus it is more of an intermediate term problem in geologic confinement. Much stable carbon occurs naturally in the environment to dilute the radioactive isotope, which amounts to about .004 milligrams for a BWR fuel assembly (Majumdar and others, 1982, p. 146). Carbon-14 is produced naturally from nitrogen in the upper atmosphere but is dispersed uniformly throughout the biosphere in a carbon-14/carbon-12 ratio of $10^{-9}$. Thus about 4 kilograms of dead carbon (older than about 50,000 years) would suffice to dilute 0.004 milligrams of carbon-14 to the natural level, if perfect mixing or exchange could occur.

Iodine-129 has a half-life of about 16 million years; the time required for appreciable radioactive delay would be several times this and far beyond reasonable geologic prediction. However, the contribution of iodine 129 to the total radioactivity of spent fuel is small; in the 1,000-year-old BWR fuel referred to in columns $A$ and $B$ of table 1 , iodine-129 would contribute only 0.005 curies (about 0.002 percent of the total) from its 36 grams.

The primary concern over iodine-129 stems from the concentration of iodine-129 by the body in the thyroid gland. Evans and others $(1980$, p. 78 ) observed that "to maintain the dose to an individual below $75 \mathrm{mrem} / \mathrm{yr}$ [milli-roentgen equivalent per year] (EPA regulation), the isotope ratio in the thyroid must be less than $0.0013 * * *$. Thus about 800 grams of iodine-127 must eventually be mixed with each gram of iodine-129 to be within the dose requirements for all future generations."

Unlike carbon, iodine usually has very low concentrations in the natural continental inorganic environment, and the requisite isotopic dilution is not readily available. Perel'man (1972) reviewed the geochemistry of iodine. He described it as a typical rare and dispersed element that migrates actively in water and in the atmosphere and concentrates in the biosphere and in living matter. Eight iodine minerals are known, but their occurrence is very rare. Most iodine ends up in the ocean, which is a huge iodine reservoir.

For reprocessed waste, Evans and others (1980) and Prout and others (1982) examined alternatives for the storage and disposal of krypton-85, carbon-14, and iodine-129 upon their release during the dissolution step in the reprocessing of spent fuel. Prout and others (p. 26) concluded that burial of iodine-129 in deep ocean sediments could provide the requisite isotopic dilution with iodine-127 and that slow diffusion through the sediments along with the movement of deep ocean currents should provide the necessary mixing. Evans and others (p. 11) similarly concluded that "deep ocean sediment disposal of iodine offers the best assurance of isotopic dilution."

Spent fuel as a waste form was reviewed by Dayal and others $(1982$, p. 95) who noted that:

Gaseous fission products such as krypton, xenon, and iodine can accumulate within the cladded fuel rods and deform the cladding. If the gases do escape through the ruptured cladding, their retention by other components of the waste package cannot be assured at present. Both their gaseous state and their varied chemical reactivities differ from other fuel waste components and tailoring of backfills and overpacks will be necessary. No specific programs dedicated to this problem have yet been generated. [Italics added.]

Thus iodine-129 presents a problem in both reprocessed and unreprocessed spent fuel. For reprocessed fuel, iodine-129 would be removed from the waste and treated as a separate disposal problem. For unreprocessed fuel, most of the gases possibly could be removed by physical and chemical means short of full scale reprocessing, (for example, perforating or chopping up of fuel elements and annealing). This solution is suggested by the following observation made by Johnson (1977, p. 18 ), in a study of the behavior of spent nuclear fuel in water pool storage:

The vast majority of failed fuel does not require special handling and is stored in the same manner as intact fuel. Two aspects of the defective fuel account for its favorable storage characteristics. First, when a fuel rod perforates in-reactor, the radioactive gas inventory is released to the reactor primary coolant.

Therefore, upon discharge, little additional gas release occurs. Only if the failure occurs by mechanical damage in the basin are radioactive gases released in detectable amounts $* * *$ 
Iodine-129 (as well as carbon-14) presents somewhat different problems for repositories in the saturated and unsaturated zones. In the saturated zone, the repository is effectively surrounded by ground water that sooner or later would pick up the iodine, probably as an anion with or without oxygen. Although engineered barriers could delay this process (Allard and others, 1980), naturally occurring minerals are unlikely to retard iodine's migration to any appreciable degree. Because of its long half-life, long ground-water traveltimes are of no particular help. The most effective protection would be dilution through slow release, preferably into waters with a high natural iodine content.

In the unsaturated zone, the problem is more complex (Evans and others, 1983, p. 177). Escaping iodine-129 might travel as iodine gas diffusing through rocks, with its movement controlled by the rocks' permeability to gases. Thus part of the iodine-129 might eventually diffuse from rocks directly into the atmosphere where it would mix with the iodine already there.

Reliable data on iodine in the atmosphere appear to be meager. Duce and others (1965) made a very comprehensive study of iodine, bromine, and chlorine in the atmosphere around and over Hawaii. The lowest values they encountered were about $2 \times 10^{-9}$ grams per cubic meter at several thousand feet on Mauna Loa. If comparable values occurred over Nevada and if perfect mixing were somehow achieved, about 18 cubic kilometers of air would be needed to dilute the 36 grams of iodine-129 in a single fuel assembly with 800 times that amount of iodine-127, assuming the iodine-129 was entirely lost to the atmosphere. Samples of rain from the same localities contained a minimum of about $0.1 \times 10^{-9}$ grams per milliliter of iodine. Thus a square kilometer would receive about 1 gram of iodine per centimeter of rainfall. Diluting 36 grams of iodine-129 by a ratio of $800: 1$ would require about $3 \times 10^{-4}$ grams of iodine-127 or about 300 centimeters (120 inches) of rain over a square 10 kilometers on a side.

These calculations are unrealistic and intended only to try to place the problem in terms that can be readily comprehended. If the iodine cannot be removed from the waste, studies should be made of rates of iodine release from the waste, and models of iodine migration, both as a gas escaping into the atmosphere and as anions moving with the ground water, need to be developed and carefully examined. The same applies to carbon-14, although the problem may be less severe because of the shorter half-life and natural abundance of nonradioactive carbon.

Leakage of radon generated by the waste should also be assessed; however, the hazard associated with a repository should be much less than the hazard presented by radon generated by uranium mine tailings because of the short half-life of radon and because the waste would be far below the surface.

\section{CONCLUSIONS}

With regard to site exploration and characterization, no apparent technical reasons exist to justify placing any limits on the numbers of drill holes used to explore a candidate repository in the unsaturated zone. Furthermore, it is difficult to conceive of any "geologic surprises" that could present serious problems in the unsaturated zone.

With regard to repository design, the problem of sealing shafts and boreholes is of little consequence in the unsaturated zone. Therefore, the number of shafts or openings into the repository need not be limited. Tunnels also do not need to be backfilled. Without backfill and with adequate ventilation, the entire repository could be accessible throughout its operational life, and the performance of both the repository and all waste packages could be readily monitored. With increased ventilation during the entire operational period, the bulk of the heat generated by the waste could be removed by allowing air to circulate around the canisters. As a result, more waste could be emplaced in the same repository volume, as the thermal loading imposed on the host rock would be greatly reduced.

Because of increased accessibility, retrieval of the waste should be simple and straightforward should the system or any components fail to perform as expected, or if retrieval of spent fuel for reprocessing were desired at some future date. Monitoring the performance of the waste package would be similarly straightforward.

Because the waste is unlikely to come in contact with any appreciable amount of water in repositories in the unsaturated zone, the performance requirements of the waste package with regard to resistance to leaching may be much less stringent than required in the saturated zone. 
In assessing the future performance of a repository, the complex problem of predicting thermalmechanical-hydrologic interactions in the saturated zone should be reduced to prediction of a much simpler thermal-mechanical interaction within a relatively dry environment. If extensive ventilation were possible as suggested in this paper, the thermal aspect of this problem would be reduced further.

Unlike conditions in the saturated zone, the direction of movement of ground water in the unsaturated zone, as well as the maximum amount that might pass through the repository over a long period of time, is readily predictable. The path is downward, and the amount is directly related to the average precipitation above the repository. Both will be verifiable by direct observations during the operation of the repository. Future human intrusion should have minor effects unless the intruders actually carry the waste to the surface.

A major new concern would be whether a change to wetter climatic conditions could result in possible future elevation of the water table to the level of the repository or a greatly increased downward flux of water. Either might increase the rate of radionuclide migration from the repository and decrease the traveltime to the accessible environment.

If spent fuel is to be placed in a repository in the unsaturated zone, a new concern that must be addressed is the possible rate of escape to the atmosphere of the gaseous radionuclides, iodine-129 and carbon-14, if they are not removed from the spent fuel and treated separately.

\section{REFERENCES CITED}

Allard, B., Torstenfelt, B., Andersson, K., and Rydberg, J., 1980, Possible retention of iodine in the ground, in Scientific Basis for Nuclear Waste Management, v. 2, Plenum Press, New York, p. 673-680.

Bird, G. W., and Lopata, V. J., 1980, Solution interaction of nuclear waste anions with selected geological materials, in Scientific Basis for Nuclear Waste Management, v. 2, Plenum Press, New York, p. 419-426.

Cameron, F. X., 1981, Human intrusion into geologic repositories for high-level radioactive waste: Potential and prevention: Radioactive Waste Management, v. 2(2), p. 179-187.

Clebsch, Alfred, Jr., 1961, Tritium age of ground water at the Nevada Test Site, Nye County, Nevada, in Short papers in the geologic and hydrologic sciences: U.S. Geological Survey Professional Paper 424-C, p. C122-C125.

Crosthwaite, J. L., Barrie, J. N., and Nuttall, K., 1980, Design, fabrication and testing of a prototype stressed-shell fuel isolation container: AECL-6823, 59 p., Atomic Energy of Canada Limited, Whiteshell Nuclear Research Establishment, Pinawa, Manitoba ROE $1 \mathrm{LO}$.

D'Appolonia Consulting Engineers, 1980, Repository sealing field testing workshop: ONWI-239, 62 p., Proceedings, prepared for the Office of Nuclear Waste Isolation, Battelle Project Management Division, Columbus, OH 43201.

1981, Sealing considerations for repository shafts in bedded and dome salt: ONWI-255, 141 p., prepared for the Office of Nuclear Waste Isolation, Battelle Project Management Division, Columbus, $\mathrm{OH} 43201$.

Dayal, R., Lee, B. S., Wilke, R. J., Swyler, K. J., Soo, P., Ahn, T. M., McIntyre, N. S., and Veakis, E., 1981, Nuclear waste management technical support in the development of nuclear waste form criteria for the NRC, task 1, waste package overview: U.S. Nuclear Regulatory Commission, NUREG/CR-2333, v. 1, 321 p.

Dixon, G. L., and Glanzman, Virginia, 1982, Search for potential sites (Nevada Test Site) [p. 7-11], in U.S. Geological Survey research in radioactive waste disposal-Fiscal year 1980: U.S. Geological Survey Open-File Report 82-509, $110 \mathrm{p}$.

Dixon, G. L., and Hoover, D. B., 1982, Search for potential sites (Nevada Test Site) [p. 4-7], in U.S. Geological Survey research in radioactive waste disposal-Fiscal year 1979: U.S. Geological Survey Circular 847, $74 \mathrm{p}$.

Duce, R. A., Winchester, J. W., and Van Nahl, T., 1965, Iodine, bromine, and chlorine in the Hawaiian atmosphere, Journal of Geophysical Research, v. 7, p. 1775-1799.

Ege, J. R., Carroll, R. D., Magner, J. E., and Cunningham, D. R., 1980, U.S. Geological Survey investigations in the U12n.03 drift, Rainier Mesa, Area 12, Nevada Test Site: U.S. Geological Survey Open-File Report 80-1074, 29 p.

Ellison, R. D., Kelsall, P. C., Schubert, C. E., and Stephenson, D. E., 1981, Developments in repository sealing design studies in 1981: Proceedings of the 1981 National Waste Terminal Storage Program Information Meeting, U.S. Department of Energy/National Waste Terminal Storage Program, DOE/NWTS-15, p. 51-54.

Evans, A. G., Prout, W. E., Buckner, J. T., and Buckner, M. R., 1980, Management of radioactive waste gases from the nuclear fuel cycle-Volume 1, Comparison of alternatives. U.S. Department of Energy, NUREG/CR-1546, v. 1, 88 p.

Evans, D. E., and Chi-hua, Huang, 1983, Role of desaturation on transport through fractured rock, in Mercer, J. W., Rao, P.S., and Marine, I. W. (ed.), Role of the unsaturated zone in radioactive and hazardous waste disposal: Ann Arbor Science Publisher, Ann Arbor, Michigan, p. 165-178.

Geotechnical Engineers, Inc., 1979, Preliminary study of radioactive waste disposal in the vadose zone: Lawrence Livermore Laboratory, UCRL $13992,74 \mathrm{p}$.

Hammond, R. P., 1979, Nuclear wastes and public acceptance: American Scientist, v. 67, p. 146-150.

Johnson, A. B., 1977, Behavior of spent nuclear fuel in water pool storage: Battelle Pacific Northwest Laboratories, BNWL-2256, 85 p.

Kaiser Engineers, Inc., 1980, Retrieval options study: ONWI-63, $235 \mathrm{p}$., prepared for the Office of Nuclear Waste Isolation, Battelle Project Management Division, Columbus, $\mathrm{OH} 43201$.

Kaplan, M. F., 1982, Archaeological data as a basis for repository marker design: ONWI-354, 83 p., prepared for the Office of Nuclear Waste Isolation, Battelle Memorial Institute, Columbus, $\mathrm{OH} 43201$. 
Klingsberg, Cyrus, and Duguid, James, 1980, Status of technology for isolating high-level radioactive wastes in geoloğic repositories: DOE/TIC 11207 (Draft), $127 \mathrm{p}$.

Lawrence Berkeley Laboratory, 1980, Proceedings, Workshop on Thermomechanical-hydrochemical modeling for a hardrock waste repository, $127 \mathrm{p}$.

Majumdar, D., and Indusi, J. P. (Part 1), Indusi, J. P., and Majumdar, D. (Part 2), and Manaktala, H. K. (Part 3), 1982, Nuclear waste management technical support in the development of nuclear waste form criteria for the NRC, Task 3, Waste Inventory Review: U.S. Nuclear Regulatory Commission, NUREG/CR-2333, vol. 3, 236 p.

National Academy of Sciences, 1978, Radioactive wastes at the Hanford Reservation, a technical review: Panel on Hanford Wastes, Committee on Radioactive Waste Management, Commission on Natural Resources, National Research Council, $269 \mathrm{p}$.

1983, A study of the isolation system for geologic disposal of radioactive waste: Waste Isolation Systems Panel, Board on Radioactive Waste Management, Commission on Physical Sciences, National Research Council, $345 \mathrm{p}$.

Nuclear Regulatory Commission, 1981, 10 CFR Part 60, Disposal of high-level radioactive wastes in geologic repositories: Federal Register, v. 46, no. 130, p. 35280-35296.

Ogard, A., Bentley, G., Bryant, E., Duffy, C., Grisham, J., Norris, E., Orth, C., and Thomas, K, 1981, Are solubility limits of importance to leaching?, in Moore, J. G. (ed.), Scientific basis for nuclear waste management, v. 3, p. 331-338.

Perel'man, A. I., 1972, Geochemistry of elements in the supergene zone [translated from Russian, 1977]. Available from National Technical Information Service, Springfield, Va.

Prout, W. E., Durant, W. S., Evans, A. G., Buckner, M. R., and Wright, W. V., 1982, Management of radioactive waste gases from the nuclear fuel cycle, v. II, Evaluation of storage/disposal alternatives: U.S. Nuclear Regulatory Commission, $101 \mathrm{p}$.

Roy, D. M., 1981, Progress in repository sealing materials studies in 1981: Proceedings of the 1981 National Waste Terminal Storage Program Information Meeting, U.S. Department of Energy/National Waste Terminal Storage Program, DOE/NWTS-15, p. 55-64.

Scott, R. B., Spengler, R. W., Diehl, Sharon, Lappin, A. R., and Chornack, M. P., 1983, Geologic character of tuffs in the unsaturated zone at Yucca Mountain, southern Nevada, in Role of the unsaturated zone in radioactive and hazardous waste disposal, Ann Arbor Science Publishers, Ann Arbor, Michigan, p. 289-335.

Schronhorst, J. R., Bolmgren, C. R., Kelley, J. L., and Newby, D., 1981, in Engineered waste-package conceptual designs: Defense high-level waste, commercial high-level waste, and spent fuel in salt and basalt geologies: Proceedings of the 1981 National Waste Terminal Storage Program Information Meeting, U.S. Department of Energy/National Waste Terminal Storage Program, DOE/NWTS-15, p. 303-306.

Spengler, R. W., Byers, F. M., and Warner, J. B., 1981, Stratigraphy and structure of volcanic rocks in drill hole USW-G1, Yucca Mountain, Nye County, Nevada: U.S. Geological Survey Open-File Report 81-1349, 50 p.

Thordarson, William, 1965, Perched ground water in zeolitizedbedded tuff, Rainier Mesa and vicinity, Nevada Test Site: U.S. Geological Survey TEI-862, Open-File Report, 90 p.

U.S. Department of Energy, 1980, In the matter of proposed rulemaking on the storage and disposal of nuclear waste (Waste Confidence Rulemaking), PR-50,51 (44 FR 61372): DOE/NE-0007.

Weitzberg, Abraham, 1982, Building on existing institutions to perpetrate knowledge of waste repositories: ONWI-379, $35 \mathrm{p}$., prepared for the Office of Nuclear Waste Isolation, Battelle Memorial Institute, Columbus, OH 43201.

Wilems, R. E., Arbital, Jeffrey, Fowler, Jim, Mosier, John, Rickertsen, Larry, Stevens, Paul, and Weaver, Boyd, 1980, Preliminary assessment of a technical basis for establishing a retrievability period, ONWI-101, 93 p., prepared for the Office of Nuclear Waste Isolation, Battelle Project Management Division, Columbus, OH 43201.

Winograd, I. J., 1972, Near surface storage of solidified highlevel radioactive waste in thick $(400-2,000$ foot) unsaturated zones in the southwest: Geological Society of America, Abstracts with Programs, v. 4, p. 708.

1974, Radioactive waste storage in the arid zone: EOS, v. 55, p. 884-894; Comments and reply, v. 57, p. 178-216.

1981, Radioactive waste disposal in thick unsaturated zones: Science, v. 212, no. 4502, p. 1457-1464.

Winograd, I. J., and Doty, G., 1980, Paleohydrology of the southern Great Basin, with special reference to water table fluctuations beneath the Nevada Test Site during the Late(?) Pleistocene: U.S. Geological Survey Open-File Report 80-569, $91 \mathrm{p}$.

Winograd, I. J., and Robertson, F. N., 1982, Deep oxygenated ground water: Anomaly or common occurrence: Science, v. 216, p. 1227-1230.

Wollenberg, H. A., Wang, J., and Korbin, G., 1982, An appraisal of nuclear waste isolation in the vadose zone in arid and semi-arid regions: Lawrence Berkeley Laboratory, Report LBL-15010, $130 \mathrm{p}$.

1983, Nuclear waste isolation in the unsaturated zone of arid regions, in Role of the unsaturated zone in radioactive and hazardous waste disposal, Ann Arbor Science Publishers, Ann Arbor, Michigan, p. 195-210.

Zen, E-an, 1980, Dedicated-site, interim storage of high-level nuclear waste as part of the management system: Proceedings, National Academy Science, v. 77, no. 11, p. 6269-6271. 